\title{
HUBUNGAN GOLONGAN DARAH DENGAN GAYA BELAJAR KOLB LEARNING STYLE INVENTORY MAHASISWA KEPERAWATAN UIN ALAUDDIN MAKASSAR
}

\author{
Muh. Anwar Hafid ${ }^{1)}$, Eny Sutria ${ }^{2)}$ \\ ${ }^{1,2}$ Departement of Nursing, Faculty Medicine and Health, Universitas Islam Negeri Alauddin \\ Makassar, Indonesia \\ e-mail : muhammadanwarhafid1562@gmail.com
}

\begin{abstract}
Abstrak
Gaya belajar merupakan cara termudah yang dimiliki oleh individu dalam menyerap, mengatur, dan mengelola informasi yang diterima. Gaya belajar yang sesuai adalah kunci keberhasilan seseorang dalam belajar. Jika keberhasilan dalam tercapainya tujuan Pendidikan bergantung pada kegiatan belajar mengajar, maka keberhasilan proses belajar mengajar itu sendiri tidak bias lepas dari gaya belajar peserta didik. Salah satu metode yang digunakan dalam menentukan gaya belajar adalah model Learning Style Inventory yang dikenalkan oleh David Kolb dan menghasilkan kesimpulan adanya empat gaya belajar yang umum, yaitu Diverger, Assimilator, Accomodator, dan Converger.

Desain penelitian ini menggunakan Total Sampling yaitu semua mahasiswa S1 keperawatan UIN Alauddin Makassar. Sampel dalam penelitian ini adalah seluruh mahasiswa Keperawatan UIN Alauddin Makassar semester II, IV, dan VI dengan jumlah 155 orang.

Hasil penelitian menunjukkan bahwa analisis bivariat yang dilakukan dalam penelitian ini dengan menggunakan uji spearman, didapatkan hasil nilai $p=0,426$ atau $p>0,05$ yang memiliki arti hipotesis nol $\left(\mathrm{H}_{0}\right)$ diterima karena kekuatan korelasi antar variabel yang lemah selain itu nilai $\mathrm{r}=-.064$ yang berarti korelasi positif sehingga hipotesis nol $\left(\mathrm{H}_{0}\right)$ diterima yakni tidak ada hubungan yang signifikan antara golongan darah dengan gaya belajar Kolb.

Hasil penelitian ini direkomendasikan bagi institusi Keperawatan UIN Alauddin Makasssar agar dapat memperhatikan gaya belajar mahasiswa sesuai dengan karakteristiknya sehingga proses belajar mengajar menjadi lebih efektif.
\end{abstract}

Kata Kunci: Golongan darah, Jenis Gaya Belajar, Kolb Learning Style

\begin{abstract}
Learning style is the easiest way that is owned by individuals in absorbing, managing, and managing information received. The appropriate learning style is the key to one's success in learning. If success in achieving educational goals depends on teaching and learning activities, the success of the teaching and learning process itself cannot be separated from the learning styles of students. One method used in determining learning styles is the Learning Style Inventory model introduced by David Kolb and concludes that there are four common learning styles, namely Diverger, Assimilator, Accommodation, and Converger.

The design of this study uses Total Sampling which is all nursing undergraduate students of UIN Alauddin Makassar. The sample in this study were all nursing students of the second, fourth and sixth semester of UIN Alauddin Makassar with 155 people.The results showed that bivariate analysis carried out in this study using the Spearman test, the results obtained $\mathrm{p}$ value $=0.426$ or $\mathrm{p}>0.05$ which means the null hypothesis $(\mathrm{H} 0)$ is accepted because the strength of the correlation between variables is weak besides the value $r=-$
\end{abstract}


.064 which means a positive correlation so the null hypothesis (H0) is accepted, namely there is no significant relationship between blood type and learning style Kolb.

The results of this study are recommended for UIN Alauddin Makasssar Nursing institutions in order to pay attention to student learning styles according to their characteristics so that the teaching and learning process becomes more effective.

Keywords: Blood Type, Learning Style Type, Kolb Learning Style

\section{PENDAHULUAN}

Salah satu perubahan yang dilakukan pemerintah dalam meningkatkan kualitas pendidikan adalah dengan diterbitkannya peraturan pemerintah nomor 32 tahun 2013 tentang standar nasional Pendidikan pasal 19 disebutkan bahwa proses pembelajaran pada satuan Pendidikan diselenggarakan secara interaktif, inspiratif, menyenangkan, menantang, memotivasi peserta didik untuk berpartisipasi aktif, serta memberikan ruang yang cukup bagi kreatifitas, dan kemandirian sesuai dengan bakat, minat dan perkembangan fisik serta psikologis peserta didik. Hal tersebut mengisyaratkan bahwa dalam proses pembelajaran seorang guru harus memperhatikan karakteristik peserta didik sehingga tercapai proses pembelajaran yang efektif

Berdasarkan data UNESCO tahun 2017 yang berisi pemantauan pendidikan negara - negara ASEAN, Education Development Index (EDI) Indonesia berada diperingkat 108 di dunia dengan skor 0,603 . Kondisi ini mencerminkan perkembangan pendidikan di indonesia masih tertinggal dibandingkan dengan Negara berkembang lainnya (UNESCO, 2017).

Saat ini berbagai lembaga pendidikan tinggi berkompetisi untuk menghasilkan lulusan yang memiliki kualitas yang baik sehingga berbagai metode serta fasilitas yang mendukung dalam pembelajaran disediakan guna mendukung proses belajar, sehingga mahasiswa memiliki kemampuan yang memadai saat lulus nanti (Arjanggi\& Suprihatin, 2010).

Menurut Ghufron dan Risnawita (2012) bahwa setiap individu memiliki ciri khas masing-masing, sehingga tidak ada dua individu yang sama, setiap individu adalah unik. Proses pembelajaran ini ada yang berorientasi kepada mahasiswa selaku peserta didik, ada juga yang berpusat pada dosen yang mengajar. Aktivitas pembelajaran tersebut merupakan perilaku individual yang spesifik, masing-masing memiliki gaya belajar dan gaya mengajar, yang menggambarkan gaya-gaya kepribadian individu yang bersangkutan.

Mengenali gaya belajar sendiri, belum tentu membuat seseorang menjadi lebih pandai tetapi dengan mengenal gaya belajar seseorang akan dapat menentukan cara belajar yang lebih efektif. Mahasiswa program studi Keperawatan sangat kompleks dan berasal dari latar belakang daerah, suku dan etnis yang berbeda - beda. Dengan kondisi seperti ini tentu dosen sangat memeras keringat dalam memberikan kuliah mengingat betapa sulitnya mengakomodasi gaya belajar tiap tiap mahasiswa. Kadang - kadang mungkin dalam proses belajar mengajar menjadi tidak efektif bahkan materi yang disampaikan sulit diterima oleh mahasiswa. Upaya untuk mencari jalan keluar dalam menanggulangi permasalahan tersebut, yaitu dengan cara mengenali gaya belajar masing - masing mahasiswa sehingga hasil belajar yang diperoleh dapat maksimal.

Salah satu instrumen untuk mengetahui gaya belajar telah dikembangkan oleh David Kolb, Ph.D dan dinamakan LSI, Learning Style Inventory pada tahun 1971. Hasil penelitian dan observasi klinis yang didasarkan pada LSI telah menghasilkan kesimpulan adanya empat gaya belajar yang umum, yaitu Diverging, Assimilating, Accomodating, dan Converging.

Karakter merupakan jati diri, kepribadian, dan watak yang melekat pada diri seseorang 
(Ghufron,2010). Karakteristik peserta didik berhubungan dengan aspek - aspek yang melekat pada peserta didik, seperti motivasi, kemampuan awal, gaya belajar, kepribadian dan sebagainya (Wena,2011). Akan tetapi, untuk menetapkan semua karakteristik tersebut dalam sebuah strategi atau metode tidaklah mudah.

Ada beberapa cara untuk mengetahui karakteristik peserta didik, diantaranya adalah dengan menggunakan sistem penggolongan darah $\mathrm{ABO}$. Golongan darah merupakan sistem pengelompokan darah yang didasarkan pada jenis antigen yang dimilikinya. Sedikitnya ada 48 jenis antigen yang menjadi dasar dalam penggolongan darah. Tetapi yang paling umum digunakan adalah sistem penggolongan darah ABO. Pembagian golongan darah sistem $\mathrm{ABO}$ didasarkan pada adanya perbedaan aglutinogen (antigen) dan aglutinin (antibodi) yang terkandung dalam darah (Nadia, dkk., 2010).

Gambaran karakteristik berdasarkan sistem penggolongan darah $\mathrm{ABO}$ telah diteliti oleh beberapa ilmuan jepang sejak tahun 1930an, diantaranya adalah Toshitaka Nomi. Hasil penelitian Toshtika Nomi mengungkapkan bahwa setiap golongan darah memiliki ritmeemosi dan ritme belajar yang berbeda - beda ( Nomi,2007).

Golongan darah manusia bersifat herediter (pewarisan atau penurunan) dan sangat tergantung pada golongan darah kedua orang tua manusia yang bersangkutan. Salah satu sistem golongan darah yang digunakan dalam penelitian ini adalah sistem golongan darah ABO yang diperkenalkan oleh Karl Landsteiner (18681943) pada tahun 1903. Menurut Landsteiner, darah manusia mengandung aglutinogen (antingen) yang terdapat pada permukaan eritrosit dan aglutinin (antibodi) yang terdapat didalam plasma darah. Antingen dibedakan menjadi dua, yaitu antingen A dan B. Sedangkan aglutinin dibedakan menjadi aglutinin dan aglutinin . Darah seseorang memungkinkan dapat mengandung antingen A saja atau antingen $\mathrm{B}$ saja, dapat mengandung kedua antingen A dan B, bahkan ada yang tidak mengandung antingen sama sekali. Ada tidaknya antingen inilah yang menjadi dasar penggolongan darah manusia berdasarkan sistem $\mathrm{ABO}$ yang terdiri dari golongan darah $\mathrm{A}, \mathrm{B}, \mathrm{AB}$, dan $\mathrm{O}$.

Penelitian tentang golongan darah dan kaitannya dengan kepribadian telah banyak diteliti baik oleh ilmuwan jepang ( Nomi,2007). Korea (Lee dan Chin,2014). India (Ahmadi, et.al.2013). iran (Alizadeh, et.al.2013), dan Indonesia (Permatasari,2012 : Dwipayama 2013 : Tenriawaru dkk. 2016). Akan tetapi ulasan kaitan antara golongan darah dengan karakteristik peserta didik dalam belajar masih sangat sedikit. Oleh karena itu, peneliti tertarik untuk mengetahui hubungan golongan darah $\mathrm{A}, \mathrm{B}, \mathrm{O}$, dan $\mathrm{AB}$ terhadap gaya belajar mahasiswa.

Studi pendahuluan yang dilakukan pada mahasiswa S1 jurusan keperawatan didapatkan adanya perbedaan karakteristik antara satu mahasiswa dengan mahasiswa lainnya. Berdasarkan hal yang telah disebutkan tadi, peneliti tertarikuntuk mengkaji hubungan Golongan Darah Tipe ABO terhadap gaya belajar KolbLearning Style Inventory. Adapun penelitian akan dilakukan pada mahasiswa keperawatan UIN Alauddin Makassar yang masih aktif dalam proses pembelajaran. Hasil penelitian ini akan bermanfaat sebagai bahan pertimbangan bagi mahasiswa untuk mengetahui hubungan golongan darah dengan karakteristik gaya belajar sehingga mempermudah proses dalam pemilihan metode teknik atau jenis bahan ajar yang sesuai dengan kebutuhan dan gaya belajar mahasiswa sehingga diharapkan kualitas pembelajaran di jurusan keperawatani menjadi lebih baik. 


\section{METODE}

Metode penelitian yang akan dilakukan pada penelitian ini adalah metode kuantitatif dengan desain peneliti Cross Sectional dengan tujuan untuk mengetahui hubungan variabel independent dengan variabel dependent (Sugiyono, 2012).

Penelitian ini dilakukan di Keperawatan UIN Alauddin Makassar dan Waktu

Penelitian ini dilaksanakan pada bulanMaret 2018. Populasi dalam penelitian ini adalah mahasiswa S1 Keperawatan semester II, IV, dan VI dengan jumlah 156 orang. Teknik sampling yang digunakan dalam penelitian ini adalah sampling jenuh, dimana semua anggota populasi dijadikan sampel dengan kriteria:

1. Kriteria Inklusif

a. Semua mahasiswa Keperawatan yang berada pada semester dua,empat, dan enam.

b. Mahasiswa yang siap jadi responden

c. Mahasiswa yang hadir pada saat penelitian

2. Kriteria Eksklusi

a. Mahasiswa tidak kooperatif Sumber Data terdiri dari data primer yang diperoleh langsung dari responden, dan data sekunder diperoleh dari institusi yang akan menjadi tempat penelitian dan data-data lain yang mendukung.

Instrumen penelitian yang digunakan dalam penelitian ini adalah dengan menggunakan lembar observasi yang berisi tentang pengkajian gaya belajar. Instrumen pengukuran gaya belajar yang digunakan mengacuh pada instrument penelitian yang telah dilakukan oleh Sulaeman Hadi Sukmana (2017) yang berjudul " Analisa kecenderungan dan jenis gaya belajar menggunakan metode learning style inventory (LSI).

\section{HASIL DAN PEMBAHASAN}

Analisis yang digunakan mencakup analisis univariat yang bertujuan untuk
Gaya belajar responden diukur dari total skor jawaban responden. Gaya belajar responden dinilai berdasarkan nilai ratarata yang diperoleh secara keseluruhan. Jumlah nilai yang didapatkan dari lembar kuisioner gaya belajar dijumlahkan dan hasil penelitian ini diklasifikasikan menjadi 4 kategori yakni : Diverger,Assimilator, Converger, dan Accomodator. Dan golongan darah diperoleh dari hasil pemeriksaan golongan darah.

Data yang sudah terkumpul selanjutnya akan diolah dan dianalisis dengan teknik statistik. Proses pemasukan data dan pengelolahan data menggunakan aplikasi perangkat lunak komputer dengan penggunaan program SPSS. Pada penelitian ini menggunakan dua cara dalam menganalisis data, yaitu anaisis data Univariat dan bivariat.

Masalah etika dalam penelitian menghormati harkat dan martabat manusia (respect for human dignity) dengan mempersiapkan formulir persetujuan subyek (informed consent) dan menghormati privasi dan kerahasiaan subyek penelitian (respect for privacy and confidentiality), Keadilan dan inklusivitas (respect for justice and inclusiviness) bahwa penelitian dilakukan secara jujur, hatihati, profesional, berperikemanusiaaan dan memperhatikan faktor-faktor ketepatan, keseksamaan, kecermatan, intimitas, psikologis serta perasaan religius subyek penelitian. Peneliti meminimalisasi dampak yang merugikan bagi subyek (nonmaleficience). Apabila intervensi penelitian berpotensi mengakibatkan cedera atau stres tambahan maka subyek dikeluarkan dari kegiatan penelitan untuk mencegah terjadinya cedera, kesakitan, stres, smaupun kematian subyek penelitian.

menggambarkan keadaan variable penelitian, yaitu golongan darah dan 
gaya belajar kolb Analisis univariat, sedangakan analisis bivariat dilakukan untuk mengetahui hubungan antara Golongan Darah dan gaya belajar Kolb dengan menggunakan uji Spearman.

\section{Analisis Univariat}

Dari pengumpulan hasil kuisioner didapatkan sebanyak 155 kuisioner yang telah di isi. Jumlah ini dianggap cukup karena telah mewakili populasi mahasiswa jurusan Keperawatan yang

Tabel 1 masih aktif dalam proses perkuliahan.

\section{Distribusi frekuensi jenis kelamin keseluruhan responden mahasiswa jurusan} Keperawatan UIN Alauddin Makassar

\begin{tabular}{ccc}
\hline Jenis Kelamin & Jumlah Responden & Presentase \\
\hline Laki - laki & 19 & $12,3 \%$ \\
\hline Perempuan & 136 & $87,7 \%$ \\
\hline Total & $\mathbf{1 5 5}$ & $\mathbf{1 0 0} \%$
\end{tabular}

Berdasarkan pada table 1 menunjukkan bahwa responden berjenis perempuan sebanyak 136 orang ( $87,7 \%$ ) dan responden laki laki sebanyak 19 orang ( $12,3 \%)$. Hal ini disebabkan karena program studi keperawatan lebih popular dikalangan perempuan sehingga jumlah perempuan lebih banyak

dibanding laki - laki pada suatu kelas.

Jumlah semester yang dijadikan responden adalah tiga semester, dimana masing - masing semester sudah didapatkan data yang berasal dari hasil kuisioner. Berikut adalah demografi jumlah responden.

Tabel 2

Distribusi frekuensi jumlah responden persemester mahasiswa jurusan Keperawatan UIN Alauddin Makassar

\begin{tabular}{ccc}
\hline Semester & Jumlah Responden & Presentase \\
\hline Semester 2 & 64 & $41,3 \%$ \\
\hline Semester 4 & 38 & $24,5 \%$ \\
\hline Semester 6 & 53 & $34,2 \%$ \\
\hline Total & $\mathbf{1 5 5}$ & $\mathbf{1 0 0} \%$ \\
\hline
\end{tabular}

Berdasarkan table 2 menunjukkan bahwa semester 2 memiliki jumlah responden sebanyak 64 orang (41,3\%), semester 4 memiliki jumlah responden sebanyak 38 orang $(24,5 \%)$, dan semester 6 memiliki jumlah responden sebanyak 53 orang $(34,2 \%)$. Perbedaan yang ditunjukkan disebabkan jumlah mahasiswa persemester yang berbeda sehingga menghasilkan jumlah responden yang berbeda tiap kelasnya 
Tabel 3. Distribusi responden menurut golongan darah

\begin{tabular}{lll}
\hline Golongan Darah & Jumlah & Presentase \\
\hline Golongan Darah A & 39 & $25,2 \%$ \\
Golongan Darah B & 52 & $33,5 \%$ \\
Golongan Darah O & 44 & $28,4 \%$ \\
Golongan Darah AB & 20 & $12,9 \%$ \\
Jumlah & $\mathbf{1 5 5}$ & $\mathbf{1 0 0 \%}$ \\
\hline
\end{tabular}

Sumber: Data Primer, 2018

Distribusi responden menurut golongan darah menunjukkan sebagian besar responden memiliki golongan darah B, yaitu sebanyak 52 responden $(33,5 \%)$, selanjutnya golongan darah $\mathrm{O}$ sebanyak 44 responden $(28,4 \%)$, golongan darah A sebanyak 39 responden $(25,2 \%)$, dan AB sebanyak 20 responden $(12,9 \%)$. Distribusi golongan darah

\section{Kecenderungan Gaya Belajar}

Kecenderungan gaya belajar menentukan bagaimana seseorang ketika melakukan proses belajar. Berikut ini merupakan data olahan hasil kuisioner untuk mengetahui responden menunjukkan sebagian besar merupakan golongan darah $\mathrm{B}$ dan O. Distribusi golongan darah responden terendah menunjukkan adalah golongan darah $\mathrm{AB}(9 \%)$, hal tersebut sesuai dengan pendapat Chieko dan Holy (2002) yang mengungkapkan bahwa golongan darah $\mathrm{AB}$ hanya tersebar kepada sekitar $6 \%$ penduduk dunia.

nilai presentase dari masing - masing semester dan keseluruhan mahasiswa jurusan keperawatan yang akan disajikan dalam bentuk diagram presentase :

\section{Diagram 1 Kecenderungan gaya belajar mahasiswa semester II}

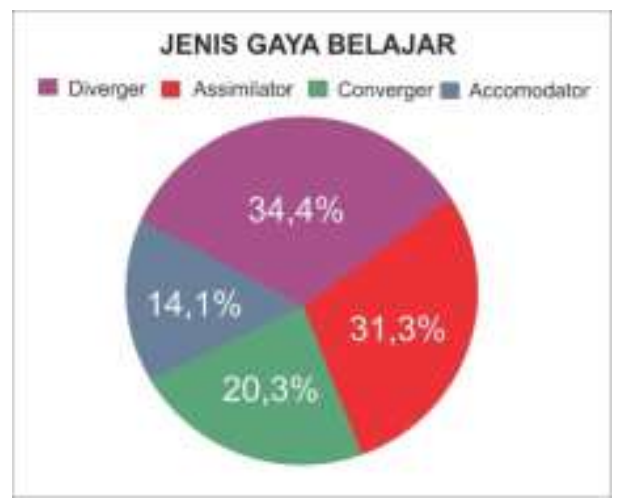

Pada hasil diagram 1 diatas menunjukkan bahwa gaya belajar mahasiswa keperawatan semester 2 didominasi oleh gaya belajar diverger dengan presentase sebanyak $34,4 \%$ (22 orang), kemudian assimilator tidak terlalu jauh dari gaya belajar diverger yaitu sebanyak
$31,3 \%$ (20 orang), converger sebanyak $20,3 \%$ (13 orang), dan accommodator sebanyak $14,1 \%$ (9 orang) dari jumlah 64 mahasiswa yang mengisi kuisioner. 


\section{Diagram 2 Kecenderungan gaya belajar mahasiswa semester IV}

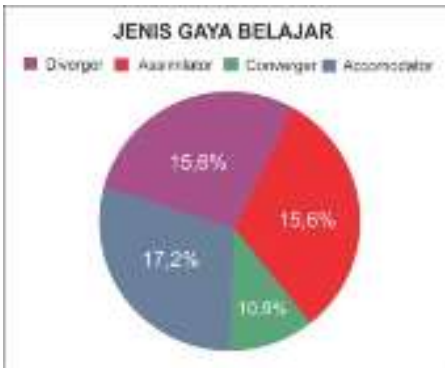

Pada diagram 2 menunjukkan presentase gaya belajar semester empat dimana gaya belajar accommodator unggul dengan presentase sebanyak $17,2 \%$ (11 orang), kemudian diikuti dengan gaya belajar diverger dan assimilator dengan presentase yang sama sebanyak $15,6 \%$ (10 orang $)$, dan converger sebanyak $10,9 \%$ (7 orang), dari jumlah 38 mahasiswa yang mengisi kuisioner.

\section{Diagram 3 Kecenderungan gaya belajar mahasiswa semester VI}

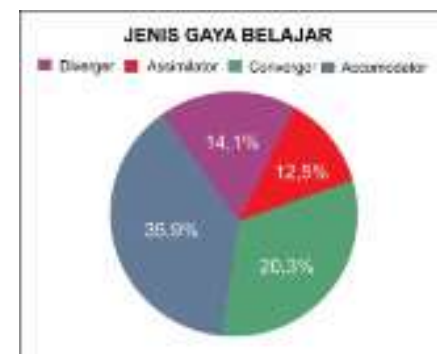

Pada hasil diagram diatas menunjukkan presentase gaya belajar semester VI didominasi oleh gaya belajar Accomodator dengan presentase sebanyak $35,9 \% \quad(23$ orang), kemudian converger

sebanyak $20,3 \% \quad(13 \quad$ orang $)$, divergersebanyak $14,1 \%$ ( 9 orang), dan asssimilator sebanyak $12,5 \%(8$ orang) dari jumlah 64 mahasiswa yang mengisi kuisioner.

Untuk mengetahui hubungan golongan darah dan gaya belajar Kolb dengan menggunakan uji Spearman .

Tabel 5

Analisis Hubungan Golongan Darah dan Gaya Belajar Kolb Learning Syle Inventory

\begin{tabular}{lllc}
\hline \multicolumn{1}{c}{ Variabel } & $\mathbf{r}$ & P value & $\mathbf{N}$ \\
\hline $\begin{array}{l}\text { Golongan Darah } \\
\text { Gaya Belajar }\end{array}$ & $\mathrm{r}=0,64$ & $\begin{array}{l}\mathrm{p}=0,64 \\
(\mathrm{p}>0,05)\end{array}$ & $\mathrm{n}=155$ \\
\end{tabular}

Sumber: Data Primer, 2018

Hasil dari uji spearman didapatkan nilai $\mathrm{p}>0,05$ dan nilai $\mathrm{r}=0,64$ yang berarti korelasi positif dengan kekuatan korelasi yang lemah sehingga hipotesis nol $\left(\mathrm{H}_{0}\right)$ diterima yakni tidak 
ada hubungan yang signifikan antara Berdasarkan hasil penelitian, didapatkan data bahwa terdapat empat jenis gaya belajar mahasiswa prodi jurusan keperawatan, meliputi gaya belajar diverger, assimilator, converger, dan accommodator dengan dominasi gaya belajar masing- masing memiliki tingkatan yang berbeda. Hasil penelitian tersebut menunjukkan gaya belajar diverger lebih didominasi pada mahasiswa semester II. Gaya belajar diverger merupakan kombinasi dari Concrete experience dan Reflective observation (feeling and watching). Kemampuan mahasiswa dengan gaya belajar diverger pada kuadran CE (concrete experience) selalu melibatkan diri sepenuhnya dalam pengalaman baru dengan perlibatan perasaan. Sedangkan kuadran RO (reflective observation)individu mengobservasi atau memikirkan pengalamannya dalam berbagai segi dengan cara mengamati.

Hal ini menunjukkan bahwa gaya belajar mahasiswa tersebut membentuk pengalaman belajar melalui menghayati sendiri secara konkret, kemudian mentransformasikan kedalam pengamatan reflektif. Mahasiswa dengan tipe diverger unggul dalam melihat situasi konkret dari banyak sudut pandang yang berbeda kemudian menghubungkannya menjadi suatu yang bulat dan utuh. Pendekatannya pada setiap situasi yaitu "mengamati" dan bukan "bertindak".

Mahasiswa tipe ini lebih menyukai tugas belajar yang menuntut menghasilkan ide-ide, gagasan dan biasanya juga menyukai mengumpulkan berbagai sumber informasi dan senang berkelompok. Mahasiswa dalam belajarnya biasanya lebih banyak bertanya Mengapa (Why). Sehingga diharapkan dosen dalam melaksanakan proses pembelajaran golongan darah dan gaya belajar kolb. berperan dan berfungsi sebagai motivator. Di sisi lain gaya belajar diverger memiliki kelemahan dimana cepat bosan jika persoalan membutuhkan waktu yang lama untuk dapat dipahami, dipecahkan, atau diselesaikan (Ghufron \& Rismawati, 2012).

Tahap ini individu sudah mampu mengadakan observasi aktif terhadap kejadian itu, serta mulai berusaha memikirkan dan memahaminya. Inilah yang terjadi dalam kombinasi pengamatan aktif dan reflektif (Hamzah, 2008)

Dalam penelitian Eka \& Ernawati (2017) menunjukkan bahwa gaya belajar diverger kebanyakan dengan sebatas mengamati sesuatu yang baru dalam pengalaman belajarnya dan sangat cocok dengan kondisi dimana dosen memberikan penanaman konsep yang kuat, namun dalam prakteknya bahwa individu yang memiliki gaya belajar ini cepat bosan jika proses pembelajaran membutuhkan waktu yang lama.

Analisis gaya Belajar Accomodator Dari hasil penelitian tersebut didaptkan gaya belajar accommodator menjadi gaya belajar yang paling dominan pada mahasiswa semester IV dan semester VI. Gaya belajar accommodator adalah kombinasi dari Concret eexperience dan Active Experimentation (feeling and doing) dimana mahasiswa yang memiliki gaya belajar tersebut senang menafsirkan pengalaman melalui menghayati sendiri secara konkret dan mentransformasi pengalamannya ke eksperimentasi aktif.Pada kuadran CE (concreteexperience) individu belajar melalui perasaan, dengan menekankan pada segi - segi pengalaman konkrit. Individu yang berada pada kuadran ini suka dengan pengalaman - pengalaman baru dan ingin segera mengalaminya. Individu yang berada pada kuadran ini juga tidak takut untuk mencoba, 
senang berkumpul dengan orang lain, berusaha keras memecahkan permasalahan yang dihadapinya dengan bertukar pikiran dengan teman - teman atau kumpulannya.

Sedangkan pada kuadran AE (active Experimentatio) individu belajar melalui tindakan, kuat dalam segi kemampuan melaksanakan tugas, berani mengambil resiko, dan mempengaruhi orang lain lewat perbuatannya. Dalam proses belajar, individu akan menghargai keberhasilannya dalam menyelesaikan pekerjaan. Individu yang berada pada kuadran ini sering mencoba - coba teori, ide dan teknis dalam melakukan sesuatu, menyenangi hal - hal yang berhubungan dengan aplikasi, ingin cepat dalam mendapatkan sesuatu dan segera melakukannya dengan kepercayaan diri yang tinggi. Dapat disimpulkan bahwa individu dalam kuadran AE ini menyukai hal - hal yang bersifat praktek dan hal baru yang dianggapnya sebagai tantangan.

Pada hasil penelitian ini menunjukkan bahwa mahasiswa keperawatan semester IV dan VI didominasi oleh gaya belajar accommodator dikarenakan mahasiswa pada semester tersebut telah melakukan pengalaman pembelajaran yang telah dilaluinya. Individu dengan gaya belajar accomodator memiliki kemampuan belajar yang baik dari hasil pengalaman nyata yang dilakukannya sendiri.Pada tahap akhir, individu sudah mampu mengaplikasikan satu aturan umum ke situasi yang baru dalam artian individu telah mampu melakukan sebuah lompatan

Hasil penelitian Eka \& Ernawati (2017) juga menunjukkan bahwa gaya belajar accommodator cenderung memiliki nilai rata - rata hasil belajar afektif yang tertinggi dibandingkan tiga gaya belajar lainnya. Kutub kecenderungan active Experimentation (doing) yang ada dalam diri individu dengan gaya belajar accommodator membuat individu tersebut aktif dalam proses pembelajaran

Gaya belajar accommodator yang dominan pada mahasiswa di semester IV dan VI menunjukkan bahwa mahasiswa tersebut belajar dari pengalaman yang telah maupun yang akan dihadapinya. Mereka juga belajar dari praktek atau pun terjun langsung ke lapangan. Pada praktiknya, kurikulum prodi keperawatan juga menunjukkan bahwa pada proses pembelajaran praktik klinikdi semester tersebut diharapkan mampu melakukan tindakan keperawatan berdasarkan hasil pengamatan yang telah dilakukan dalam pembelajaran labs skill. Mahasiswa dituntut untuk melakukan tindakan keperawatan procedural yang telah diajarkan untuk selanjutnya dapat di praktekkan dalam kondisi yang nyata.

Dalam proses belajar, mahasiswa tipe accomodator biasanya lebih banyak bertanya Bagaimana Jika (What If). Untuk itu, peran dan fungsi Dosen dalam melaksanakan proses belajar mengajar yang cocok untuk menghadapi Mahasiswa tipe ini adalah menghadapkan Mahasiswa pada pertanyaan - pertanyaan terbuka "open-ended questions". Adapun Penggunaan Metode pembelajaran yang disarankan adalah Pembelajaran berbasis masalah, Problem-Based Learning adalah pengajaran berdasarkan masalah merupakan suatu pendekatan pembelajaran di mana peserta didik mengerjakan permasalahan yang autentik dengan maksud untuk menyusun pengetahuan mereka sendiri, mengembangkan kemandirian, dan percaya diri, menurut Arends dalam (Trianto,2010)

Gaya Belajar Assimilator, dimana pada mahasiswa semester II, terdapat sebanyak $31 \%$ ( 20 orang ), semester IV sebanyak $15,6 \%$ ( 10 orang ), dan semester VI sebanyak $12,5 \%$ ( 8 orang 
). Mahasiswa yang memiliki gaya belajar ini cenderung lebih teoritis dalam berbagai hal dengan kekuatan watching dan thinking. Gaya belajar assimilator dimana individu yang menangani pengalaman melalui konseptualisasi secara abstrak (watching) dan mentransformasi ke dalam pengamatan reflektif (thinking). Individu dengan tipe assimilator memiliki kelebihan dalam memahami berbagai sajian informasi serta merangkumnya dalam suatu format yang logik, singkat, dan jelas. Biasanya individu gaya belajar ini kurang perhatian kepada orang lain dan lebih menyukai ide serta konsep yang abstrak dan cenderung teoritik. Mahasiswa dengan gaya belajar assimilator biasanya lebih banyak bertanya Apa/apakah (What). Dengan demikian, peran dan fungsi dosen yang cocok untuk menghadapi Mahasiswa tipe ini adalah sebagai seorang Expert. Dosen dalam pembelajaran berperan dan berfungsi sebagai seorang ahli (expert). Adapun metode pengajaran yang tepat pada gaya belajar ini adalah Kontextual Intructiondimana dosen menjelaskan bahan kajian yang bersifat teori dan mengaitkannya dengan situasi nyata dalam kehidupan sehari hari.

Analisis gaya Belajar Converger Hasil gaya belajar converger pada penelitian tedapat sebanyak $20 \%$ ( 13 orang ) pada mahasiswa semester II, $10,9 \%$ ( 7 orang ) pada mahasiswa

\section{Analisa Bivariat}

Analisis bivariat yang dilakukan dalam penelitian ini dengan menggunakan uji spearman. Uji Spearman digunakan untuk kategori data numerik. Kriteria tingkat hubungan korelasi (r) pada uji spearman berkisar antara $\pm 0,00$ hingga $\pm 1,00$ yang memilki intrepretasi $0,00-0,20$ berarti

hampir tidak ada korealsi; $0,21-0,40$

berarti korelasi rendah; 0,41-0,60 semester IV, dan pada mahasiswa semester VI sebanyak 20,3\% ( 13 orang ). Merupakan gaya belajar yang merupakan kombinasi dari Abstract Conceptualization dan Active Experimentation (thinking and doing), dimana gaya belajar converger dengan membentuk pengalaman melalui konseptualisasi abstrak dan mentransformasi kedalam eksperimentasi aktif. Individu dengan tipe konverger unggul dalam menemukan fungsi praktis dari berbagai ide dan teori.Individu biasanya mempunyai kemampuan yang baik dalam pemecahan masalah, pengambilan keputusan, cenderung lebih menyukai tugas-tugas teknis (aplikatif) daripada masalah sosial, manusia dan hubungan antar pribadi.Mahasiswadengan tipe gaya belajar konverger biasanya lebih banyak bertanya Bagaimana (How). Peran dan fungsi Dosen yang cocok untukmenghadapi Mahasiswa tipe ini adalah sebagai seorang Pelatih (Coach) dengan menyediakan praktik terbimbing dan memberikan umpan balik yang tepat. Dosen dalam pembelajaran berperan dan berfungsi sebagai seorang ahli(expert). Adapun metode pengajaran yang tepat pada gaya belajar ini adalah Metode Praktikum / Labskill dimana pengalaman belajar dibentuk dari hasil konseptualisasi pemikiran dan mentransformasikan dalam tindakan yang nyata.

berarti korelasi sedang; $0,61-0,80$ berarti korelasi tinggi; dan 0,81-1,00 berarti korelasi sempurna. 


\section{Correlations}

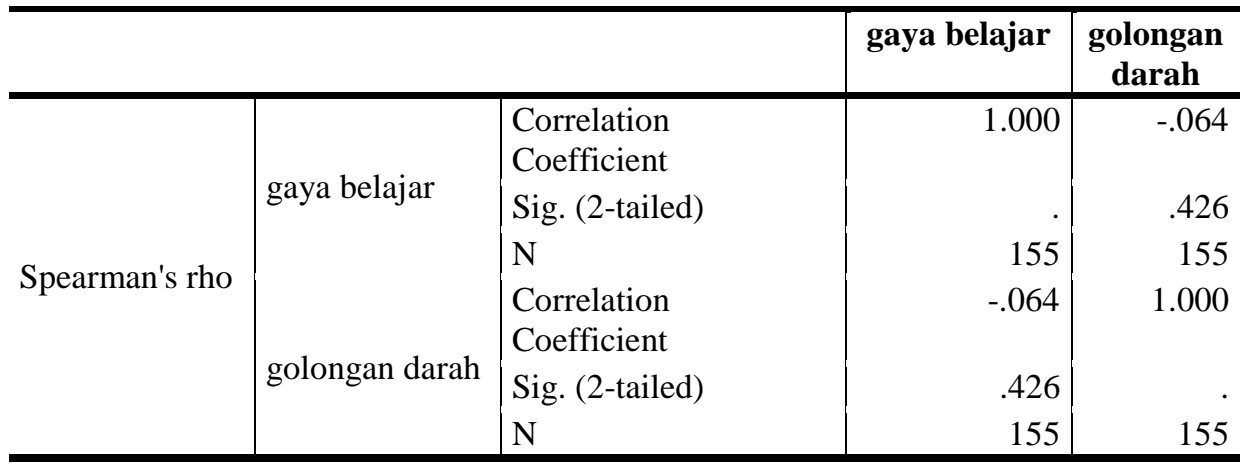

Dari hasil uji spearman didapatkan hasil nilai $p=0,426$ atau $p>0,05$ yang memiliki arti hipotesis nol $\left(\mathrm{H}_{0}\right)$ diterima karena kekuatan korelasi antar variabel yang lemah selain itu nilai $r=-.064$ yang berarti korelasi positif sehingga hipotesis nol $\left(\mathrm{H}_{0}\right)$ diterima yakni tidak ada hubungan yang signifikan antara golongan darah dengan gaya belajar Kolb.

Hasil penelitian ini sama dengan hasil yang dilakukan oleh Eka (2016) pada penelitian terkait hubungan golongan darah tipe ABO dengan gaya belajar Mahasiswa dimana tidak ada hubungan golongan darah dengan gaya belajar, ditunjukkan dengan hasil nilai signifikansi untuk semua tipe gaya belajar yang lebih besar dari pada á = 0,05 , yaitu 0,388 untuk tipe gaya belajar AE, 0,539 untuk tipe gaya belajar RO, 0,088 untuk tipe gaya belajar AC, dan 0,088 untuk tipe gaya belajar CE. Hal tersebut menunjukkan bahwa golongan darah tipe $\mathrm{ABO}$ tidak memiliki korelasi yang signifikan terhadap gaya belajar mahasiswa.

Korelasi yang tidak signifikan juga ditunjukkan oleh nilai koefisien korelasi yang mendekati 0 . Hal ini menunjukkan bahwa golongan darah tipe $\mathrm{ABO}$ dan tipe gaya belajar mahasiswa memiliki korelasi yang lemah. Hasil tersebut mengindikasikan bahwa tidak terdapat gaya belajar yang khusus untuk setiap golongan darah tipe ABO.
Perpisa dan Sevrika (2013) mengemukakan bahwa selain karakter, lingkungan juga mempengaruhi gaya belajar seseorang dan hasil penelitian lain juga ditunjukkan oleh Rosyida (2017) yang meneliti tentang hubungan golongan darah dengan gaya belajar menunjukkan Besar korelasi yang terjadi antara kedua variabel adalah 0,199 Sedangkan angka Approx. Sig. adalah 0,070 lebih besar daripada batas kritis $\alpha=0,05$, berarti tidak terdapat hubungan yang signifikan antara kedua variabel $(0,070>0,05)$.

Hasil penelitian ini berbeda dengan yang diungkapkan oleh Kim Jieun (2016) dalam bukunya, yang mengemukakan bahwa gaya belajar dapat diterapkan sesuai dengan golongan darah masing-masing individu. Perbedaan hasil ini dapat disebabkan oleh perbedaan paradigma yang berlaku di masyarakat Jepang dengan paradigma yang berlaku di masyarakat Indonesia. Paradigma yang dimaksud di sini adalah penekanan mengenai golongan darah sebagai penentu kehidupan seseorang. Masyarakat Jepang sangat mementingkan faktor golongan darah dalam kehidupan bermasyarakatnya, misalnya saja dalam hal pencarian pegawai perusahaan tertentu.

\section{KESIMPULAN}

Adapun keterbatasan peneliti selama penelitian ini adalah tidak mengukur apakah kecenderungan gaya belajar 
mahasiswa memiliki pengaruh terhadap usia dan jenis kelamin responden yang diteliti yang dimana pada dasarnya responden memiliki

\section{REFERENSI}

1. Adelia, Winda. Memahami Karakter dan Kepribadian Orang Berdasarkan Golongan Darah. Yogyakarta: SinarKejora, 2015.

2. Afandi M., Evi Chamalah., Oktarina Puspita Wardani. 2013. Model dan Metode Pembelajaran di sekolah.Unissula Press

3. Arjanggi, R. \& Suprihatin, T.2010. Metode pembelajaran tutor teman sebaya meningkatkan hasil belajar berdasarkan regulasi-diri. Mekara, Sosial Humaniora, 14(2), 91-97. Diakses dari http://journal.ui.ac.id/index.php/hum anities/article/viewFile/666/635.

4. Aljaberi, N. M.2015. University Students' Learning Styles and Their Ability toSolve Mathematical Problems. International Journal of Business andSocial Science. Vol 6, No. 4 (1).

5. Atoom, M.S. 2014. Bloods Groups and Their Relation with Intellegence among aSample of Jordanian Universities Students. Jurnal. (Online).(http://academicreasearchjo urnals.org/IJARER/index.htm, diakses pada 19Oktober 2018; 09.00 WIB).

6. Cavas, B. 2010. A Study on Preservice Science, Class, and MathematicsTeachers's Learning in Turkey. Science Education International Journal.

7. D'Amore, Angelo, Santhamma James, Eleanor K.L. Mitchell.2011. Learning Style of Firstyear Undergraduate Nursing and Midwifery Students: A Crosssectiona Survey Utilising The Kolb Learning Style Inventory. Elsevier: Nurse Educatio

8. Dikti.2013.Pedoman Program Mahasiswa perbedaan usia dan jenis kelamin dan peneliti terbatas dalam melakukan tes golongan darah karena tidak menggunakan Rhesus.

$(P M W)$.Direktorat Pembelajaran dan Kemahasiswaan Direktorat Jenderal Pendidikan Tinggi.

9. Direktorat Pembinaan Pendidikandan Pelatihan.2010. Model - Model Pembelajaran. Jakarta :Depdiknas

10.DePorter, B. \& $\mathrm{M}$. Hernacki.2008.Quantum Learning: Membiasakan Belajar.

11.Djamarah B.2008.Psikologi belajar.Jakarta: Rineka Cipta.

12.Elly Rahmawati.2016. Hubungan Gaya Belajar Terhadap Indeks Prestasi Kumulatif (IPK) Mahasiswa Fakultas Kedokteran Universitas Lampung.

13.Fistanihaya.2011.Profil gaya belajar (Learning Style) dan IPK Mahasiswa Jurusan Biologi FMIPA UNNES.Universitas Negeri Semarang.

14.Fuad jauhad.2015. Gaya Belajar Kolb Dan PercepatanBelajar.Institut. Agama Islam Tribakti Kediri.

15.Gunawan, Adi.2004. Genius Learning Strategy: Petunjuk Praktis Untuk Menerapkan Accelerated Learning. Jakarta: PT Gramedia Pustaka Utama. Cet. 2.

16. Ghufron, M. N. \& Risnawita, R.2012. Gaya Belajar: Kajian Teoretik. Yogyakarta: Pustaka Pelajar.

17.Gogus, Aytac and Gurdal Ertek.2016.Learning and Personal Attributes of University Students in Predicting and Classifying The Learning Styles: Klob's mine-region Versus four-region Learning Styles. Elsevier: Procedia Social and Behavioral Sciences.

18.Hamzah, B. U.2010.Orientasi baru dalam psikologi siswa yang memiliki gaya belajar.Jakarta:Bumi Aksara. 
19.Hay Group.2006.Kolb Learning Style Inventory. Online. http://www.haygroup.com/tl/Downl oads/LSI Slides.pdf.diaksespada 21 maret 2018

20.Indah msiyah.2012.Belajar dan Pembelajaran.Yogyakarta: Teras.

21.Kolb, A.Y. \& Kolb, D. A.2005.The Kolb Learning Style Inventory Version 3.1.

22.Kolb, David A.1984.Experiential Learning. New Jersey : Prentice Hall,Inc. Englewood Cliffs.

23.Kolb, D.A., Boyatzis, R.E. \& Mainemelis, C.2000.Experiential Learning Theory: Previous Research and New Directions. Dalam Sternberg, R.J. \& Zhang, L.S. (Eds.). Perspectives on Cognitive, Learning, and Thinking Styles. NJ: Lawrence Erlbaum.

24.Khon, Abdul Majid.2014.Hadis Tarbawi : Hadisं-Hadis pendidikan.Jakarta : Kencana,

25.Kim Jieun, "Ensiklopedia Golongan Darah", (Jakarta:Bhuana Ilmu Populer, 2016) h.98

26. Sugihartono., Fathiyah, K. N., Harahap, F., Setiawati, F. A., \& Nurhayati, S. R.2007. Psikologi pendidikan. Yogyakarta: UNY Press.

27.Sulistya ningrum, Asti. 2010. Hubungan Antara Gaya Belajar Dengan Prestasi Belajar Matematika Diantara Siswa Kelas XI IPA Dan IPS SMA Negeri 1 Salatiga Tahun Ajaran 2009/2010. Skripsi. FakultasKeguruan Dan Ilmu Pendidikan. UKSW Salatiga.

28. Manolis, Chris, David J. Burns, Rashmi Assudani, Ravi Chinta.2013.Assessing Experiential Learning Style: A Methodological Reconstruction and Validation of The Kolb Learning Style Inventory. Elsevier: Learning and Individual Differences 23:44-52
29. Michael Caesario. Medical Students Experience With Problem Based Learning in Asia : A Literature Riview.The Journal of the Indonesian Medical Student Association.Vol.I .No.1. 2010. Hal 21

30.Muhtadi Ali, karakteristik gaya belajar mahasiswa ditinjau dari preferensi sensori dan lingkungan ". jurnal Pendidikan matematika Universitas Bangka Blitung. Vol 12 No 03. Dipublikasikan, 2010.

31.Munif Chatib.2010.Sekolahnya Manusia.Bandung: Kaifa.

32.Nasution.2005. Berbagai Pendekatan dalam Proses Belajar dan Mengajar.Bandung BumiAksara.

33.Nadia, B., Handayani, D., Rismiati, R. Hidup Sehat Berdasarkan Golongan Darah O. Jakarta: Dukom Publisher.

34.Nugroho, P. U., Pajow, A. P., \& Liem, A. T.2016. Aplikasi Test Personality Dan Learning Style Inventory Berbasis Web Untuk Mahasiswa Universitas Klabat. Semnasteknomedia Online, 4(1), 3742.

35.Hartanti dan Nisya.2013.PrinsipPrinsip Dasar Keperawatan. Jakarta : Dunia Cerdas.

36.Pratiwi, D.2014.Gaya belajar dominan pada siswa berprestasi dalam kegiatan siswa yang memiliki gaya belajar di SD Negeri 2 Gombong tahun ajaran 2013/2014. Jurnal FKIP, 7(3). Diakses darihttp://jurnal.fkip.uns.ac.id/index. $\mathrm{php/pgsdkebumen/article/view/4016}$ .Diaksespada 25 maret 2018

37.Permendiknas RI No. 41 Tahun 2007 TentangStandar Proses [online] tersedia di http://bsnpindonesia.org/id/wpcontent/uploads/proses/Permen_41_ Th-2007.pdf

38.Rosidah.2014.Analisis

Gaya 
Studisiswaberprestasipada SMAN 1 dan MAN 1 Yogyakarta kelas XI. Universitas Islam NegeriSunanKalijaga Yogyakarta.

39. Sulaiman.2017.Analisakecenderung andanjenisgayabelajarmenggunakan metodeLearning Style Inventory LSI ).STMIK Nusa mandiri Jakarta.

40.Suprijono, Agus.2014. Cooperative Learning Teori dan Aplikasi Paikem.Yogyakarta: Pustaka Pelajar.

41. Siswoyo, D.2007.Ilmu pendidikan.Yogyakarta: UNY Pers.

42.Suryabrata, S.2002.Pengembangan Alat Ukur Psikologis.Jakarta : Depdikbud Dirjen Dikti.

43. Sengul, et al.2013.Learning Styles of Prospective Teachers: Kocaeli UniversityCase. Journal of Educational and Instructural Studies.

44.Slameto.2013.Belajar dan FaktorFaktor
Mempengaruhinya.Jakarta : Rineka Cipta.

45.Sugiyono.2012.Metode Penelitian Pendidikan Pendekatan Kuantitatif, Kualitatif, dan $R \& D$.Bandung: ALFABETA.

46.Suyanto.2011.Metodologi dan Aplikasi Penelitian Keperawatan.Yogyakarta: Nuha Medika.

47.Tulbure, C. (2011).Do different styles require differentiated teaching strategis?. Procedia Social and Behavioral Sciences, 11, 155-159.

48.Tohirin.2005.Psikologi

Pembelajaran Pendidikan agama Islam.Jakarta: Raja Grafindo Persada.

49.Undang-undang republik Indonesia nomor 32, pasal 19 tahun 2013.

50. Yurisa, wella.2008.Etika Penelitian Kesehatan.Riau: FKUR. 